\title{
Structural and Magnetic Properties of Cr-Zn Nanoferrites Synthesized by Chemical Co-Precipitation Method
}

\author{
Rohit R. Powar*****, Varsha D. Phadtare**, Vinayak G. Parale***, \\ Sachin Pathak***, Pravina B. Piste ${ }^{* * * *}$, and Dnyandevo N. Zambare $\mathbb{D}(* ;$ \\ *Department of Chemistry, Kisan Veer Mahavidyalaya, Wai 412803, Maharashtra, India \\ **Department of Materials Science and Engineering, Yonsei University, Seoul 03722, Korea \\ ***Department of Chemistry, Yashavantrao Chavan Institute of Science, Satara 415001, Maharashtra, India
}

(Received July 19, 2019; Revised August 12, 2019; Accepted August 13, 2019)

\begin{abstract}
Chromium-doped zinc ferrite nanoparticles with the general formula $\mathrm{Cr}_{\mathrm{y}} \mathrm{ZnFe}_{2 \mathrm{y}} \mathrm{O}_{4}(\mathrm{y}=0,0.025,0.05,0.075$, and 0.1) were synthesized by a surfactant-assisted chemical co-precipitation route using metal nitrate salt precursors. The phase purity and structural parameters were determined by powder X-ray diffraction. The concentration of $\mathrm{Cr}^{3+}$ doped into $\mathrm{ZnFe}_{2} \mathrm{O}_{4}(\mathrm{ZF})$ noticeably affected the crystallite size, which was in the range of $22 \mathrm{~nm}$ to $36 \mathrm{~nm}$, and all samples showed a single cubic spinel structure without any secondary phase or impurities. The lattice parameter, X-ray density, and skeletal density increased with an increase in the Cr-doping concentration; on the other hand, a decreasing trend was observed for the particle size and porosity. The influence of $\mathrm{Cr}^{3+}$ substitution on ZF magnetic properties were studied under an applied field of $15 \mathrm{kOe}$. The overall results revealed that the incorporation of a small amount of $\mathrm{Cr}$ dopant changed the structural, electrical, and magnetic properties of ZF.
\end{abstract}

Key words : Cr-Zn ferrites, Spinel oxides, Chemical co-precipitation, Thermal stability, Magnetic properties

\section{Introduction}

$\mathbf{R}$ ecently, tertiary mixed metal oxide nanoparticles with cubic spinel structures have been identified as the most promising materials for electrochemical energy storage applications, televisions, transformers, magnetic recording media, biomedical applications, etc., because of their exceptional physicochemical, mechanical, magnetic, and dielectric properties. ${ }^{1-6)}$ Extensive efforts have been devoted to developing a modest, stable, and effective synthesis process for nanosized materials, which can control their structural parameters and impart a high specific surface area. ${ }^{78)}$ In recent decades, size-tunable ferrite particles with a cubic spinel structure have been identified as remarkable materials because of their exceptional physicochemical properties. The cubic spinel ferrite has received significant research importance because of their outstanding, versatile, and multifield applications. Among cubic spinel ferrite materials, zinc ferrites are unique and technologically important, and find a variety of applications in water splitting, biomedicine, photocatalysts, transformer cores, microwave technology, magnetic recording media, and gas sensors. ${ }^{9-13)}$ The general formula of the cubic spinel structure is $\mathrm{AB}_{2} \mathrm{O}_{4}$, where " $\mathrm{A}$ " is a bivalent metal ion and " $\mathrm{B}$ " is a trivalent

${ }^{\dagger}$ Corresponding author : Dnyandevo N. Zambare

E-mail : dnzambare1966@gmail.com

Tel : +91-2167-220130 Fax : +91-2167-220130

ORCID

https://orcid.org/0000-0002-4294-7986 metal ion. The spinel ferrite crystal structure consists of a cubic closed arrangement of oxygen ions with 8 tetrahedral (A-site) and 16 octahedral (B-site) interstitial sites in the unit cell. ${ }^{14)}$ Therefore, in spinel ferrites, an enormous amount of vacant $A$ and $B$ positions are available for cations to migrate, amongst the interstitial sites. Nanocrystalline ntype semiconductor $\mathrm{ZnFe}_{2} \mathrm{O}_{4}$ has a typical spinel structure with $\mathrm{Zn}^{2+}$ ions at the tetrahedral interstitial sites and $\mathrm{Fe}^{3+}$ ions distributed between the tetrahedral and octahedral interstitial sites. ${ }^{15)}$ The physicochemical, electrical, and magnetic properties of spinel ferrites are noticeably affected by the addition of cations and their preferential distribution among the tetrahedral and octahedral interstitial sites, as well as particle size reduction (i.e., to produce a nanosized material) via manipulation of the preparation method to a great extent. These properties are dependent on the synthesis method, calcination temperature, compound composition, and type and concentration of the dopants. ${ }^{16,17)}$

Notably, the spinel ferrites nickel ferrite $\left(\mathrm{NiFe}_{2} \mathrm{O}_{4}\right)$ and zinc ferrite $\left(\mathrm{ZnFe}_{2} \mathrm{O}_{4}\right)$ have received extensive research interest because of their excellent chemical stability, excellent catalytic and optical properties, low cost, and facile industrial-scale preparation, and they are favorably used in the microwave industry. $\mathrm{ZnFe}_{2} \mathrm{O}_{4}$ is a soft magnetic material with unusual physical, chemical, electrical, and magnetic properties, and these properties are mostly dependent on the $\mathrm{Fe}^{2+}$ to $\mathrm{Fe}^{3+}$ transformation. In addition, the interchange of trivalent metal ions in zinc ferrite considerably affects the physicochemical, magnetic, and electrical proper- 
ties. Chromium zinc ferrites are extensively studied soft magnetic materials and they can be easily obtained via the introduction of $\mathrm{Cr}^{3+}$ ions into the unit cell of zinc ferrite because their size is analogous to that of $\mathrm{Fe}^{3+}$ ions. ${ }^{9,18-21)} \mathrm{Cur}-$ rently, nanoparticles of spinel ferrite are synthesized by different techniques such as chemical co-precipitation, ${ }^{22,23)}$ microwave combustion, ${ }^{24,25)}$ hydrothermal, ${ }^{26)}$ sol-gel, ${ }^{27)}$ and ceramic $^{28)}$ methods.

In the present work, nanoparticles of $\mathrm{Cr}^{3+}$-doped $\mathrm{ZnFe}_{2} \mathrm{O}_{4}$ with the general formula $\mathrm{Cr}_{\mathrm{y}} \mathrm{ZnFe}_{2-\mathrm{y}} \mathrm{O}_{4}(\mathrm{CrZF})$, where $\mathrm{y}=$ $0.0,0.025,0.05,0.075$, and 0.1 , were prepared by the chemical co-precipitation technique in the presence of a surfactant. This technique is a productive, cheap, and simple surfactant-assisted chemical process that can yield a large quantity of smaller particles with the preferred structure, hierarchy, and desired elemental composition at a lower sintering temperature, compared to the traditional ceramic technique. The effect of $\mathrm{Cr}$ doping (low dopant concentration) on the physicochemical properties of undoped zinc ferrite $(\mathrm{ZF})$ is reported here.

\section{Experimental Procedure}

\subsection{Synthesis and characterization}

Nanosized particles of spinel ferrite CrZF ( $\mathrm{y}=0.0,0.025$, $0.05,0.075$ and 0.1 ) were produced by a surfactant-assisted chemical co-precipitation method. The nitrate salts of metal precursors (analytical reagent) were purchased from Thomas Baker (Chemicals) Pvt. Ltd., Mumbai, India. Zinc nitrate hexahydrate $\left(\mathrm{Zn}\left(\mathrm{NO}_{3}\right)_{2} \cdot 6 \mathrm{H}_{2} \mathrm{O}\right)$, chromium nitrate nonahydrate $\left(\mathrm{Cr}\left(\mathrm{NO}_{3}\right)_{3} \cdot 9 \mathrm{H}_{2} \mathrm{O}\right)$, iron nitrate nonahydrate $\left(\mathrm{Fe}\left(\mathrm{NO}_{3}\right)_{3} \cdot 9 \mathrm{H}_{2} \mathrm{O}\right)$, n-hexadecyltrimethylammonium bromide (CTAB), 30\% aqueous ammonia $\left(\mathrm{NH}_{3}\right)$, and lab-made double distilled water were used for the synthesis. All chemicals were used as received without further refinement.

The detailed synthesis procedure of the nanoferrites has been reported in our previous publication. ${ }^{22)}$ To remove organics, the co-precipitated mixture was preheated up to $350^{\circ} \mathrm{C}$ in a muffle furnace for $2 \mathrm{~h}$. The furnace was allowed to cool down, and then, the powder was removed and milled with acetone to obtain a homogeneous mixture using pestle and mortar. The air-dried samples were heated at $750^{\circ} \mathrm{C}$ for $4 \mathrm{~h}$ in air, as depicted in Fig. 1. Finally, a soft nanocrystalline CrZF powder was obtained by milling with a pestle and mortar. The endothermic and exothermic behaviors and thermal stability of the spinel ferrites were studied by thermogravimetry-differential thermal analysis (TG-DTA, Nietzsche STA 409 TG DSE) in the temperature range from

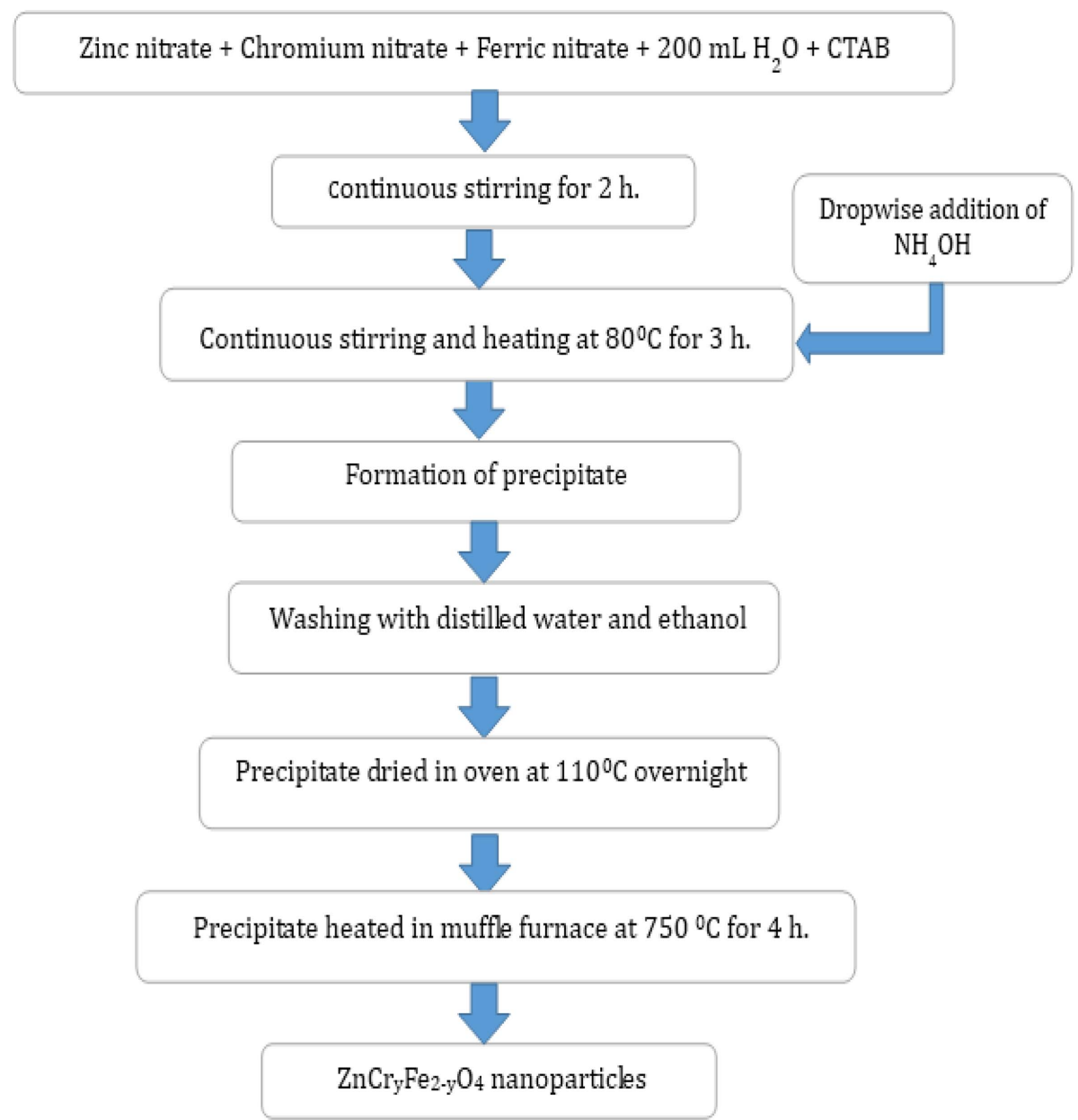

Fig. 1. Flow chart for Cr-doped zinc ferrite formation. 
$30^{\circ} \mathrm{C}$ to $1000^{\circ} \mathrm{C}$ in synthetic air at a heating rate of $10^{\circ} \mathrm{C} \cdot \mathrm{min}^{-1}$. The phase purity and structural parameters of ferrites were determined by X-ray diffraction (XRD, PW1710 Philips) with the $\mathrm{Cu} \mathrm{K} \alpha$ radiation $(\lambda=1.5405 \AA)$ in scanning range of $10-80^{\circ}$. Fourier-transform infrared (FTIR) spectroscopy (Perkin Elmer Spectrum One spectrophotometer equipped with an attenuated total reflectance (ATR) accessory) was performed using $\mathrm{KBr}$ pellets in the wavenumber range of $350-800 \mathrm{~cm}^{-1}$. The topographical microstructures of the thick film samples were determined by field-emission scanning electron microscopy (FE-SEM) using a SIGMA HV model (in the magnification range from 50x to 100,000x) equipped with an energy-dispersive X-ray (EDS) spectroscopy analyzer (for chemical composition and phase purity determination). The prepared ferrite particle dimensions were determined by a particle size analyzer. The specific surface area and pore size values were calculated using the Brunauer-Emmett-Teller (BET) and Barret-Joyner-Halenda (BJH) techniques by $\mathrm{N}_{2}$ adsorption-desorption measurements (Quantachrome Instruments v10.0). DC electrical resistivity measurements were carried out using a digital picoammeter (DPM-111) to record the current at a constant voltage across the sample by the two-probe method. Roomtemperature magnetic measurements up to a maximum field of $15 \mathrm{kOe}$ were carried out using a vibrating sample magnetometer (VSM, PAR EG\&G 4500).

\section{Results and Discussion}

\subsection{TG-DTA analysis}

The characteristic TG-DTA curve for the chemically coprecipitated CrZF sample $(y=0.05)$ is displayed in Fig. 2, from which the thermal stability and phase transition temperature of the ferrites were determined. The TG curve of the $\mathrm{ZnCr}_{0.05} \mathrm{Fe}_{1.95} \mathrm{O}_{4}$ ferrite revealed that the total weight loss was $\sim 31.5 \%$. In addition, the TG curve exhibited minor ( $\sim 9 \%$ ) and major ( $22.5 \%)$ weight loss steps in the tem-

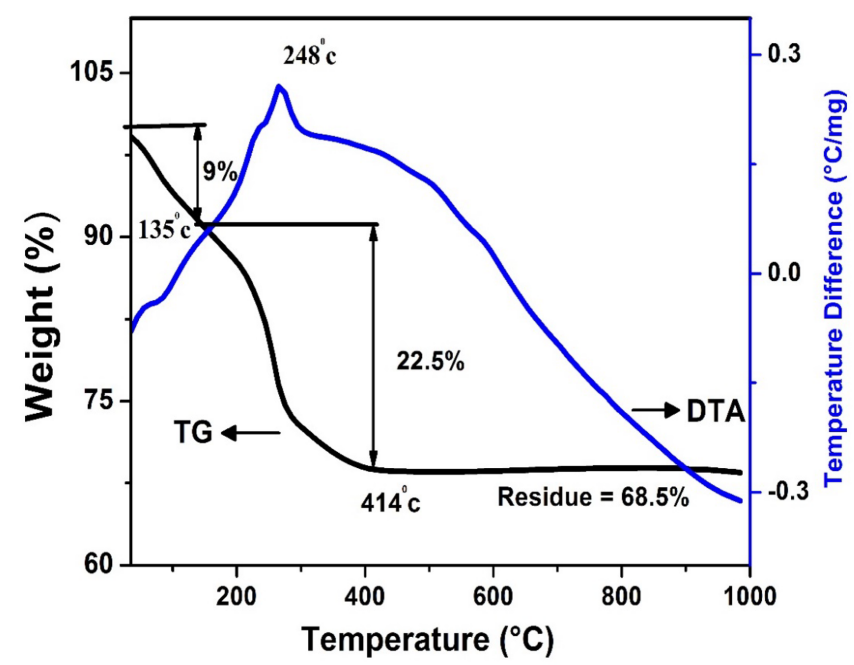

Fig. 2. TG-DTA curves of the as-prepared $\mathrm{Cr}_{\mathrm{y}} \mathrm{ZnFe}_{2-\mathrm{y}} \mathrm{O}_{4}(\mathrm{y}=$ $0.05)$ sample. perature range of $25-135^{\circ} \mathrm{C}$ and $190-320^{\circ} \mathrm{C}$, respectively. The minor weight loss was attributed to the loss of moisture and major weight loss was attributed to the decomposition of the carbon-based matrix and conversion of hydroxides into oxides. ${ }^{29)}$ No further weight loss was observed between $414^{\circ} \mathrm{C}$ and $1000^{\circ} \mathrm{C}$. The DTA curve showed a major exothermic peak at $248^{\circ} \mathrm{C}$, suggesting the occurrence of combustion of the organic matrix and conversion of the precipitate into metal oxide, which was correlated with the major weight loss step in the TG curve. The plateau observed between $415^{\circ} \mathrm{C}$ and $1000^{\circ} \mathrm{C}$ in the TG curve indicated the formation of crystalline $\mathrm{ZnCr}_{0.05} \mathrm{Fe}_{1.95} \mathrm{O}_{4}$ ferrite without any further weight loss. Thus, a single cubic spinel ferrite phase was formed due to the conversion of the valence state of the metal oxides at high sintering temperatures.

\subsection{XRD analysis}

Figure 3 presents the XRD patterns of CrZF $(y=0.0$, $0.025,0.05,0.075$, and 0.1 ) samples annealed at $750^{\circ} \mathrm{C}$ for 4 h. All XRD patterns were matched with those of $\mathrm{ZnFe}_{2} \mathrm{O}_{4}$ (JCPDS card numbers 84-0314 and 89-1012). The major diffraction peaks were assigned to the (111), (220), (311), (222), (400), (422), (511), (440), and (531) planes, and the most intense diffraction peak was assigned to the (311) plane, evidently confirming the formation of a cubic spinel structure. The lattice constant (a) was calculated using equation (1).

$$
\mathrm{a}=\mathrm{d}\left(\mathrm{h}^{2}+\mathrm{k}^{2}+\mathrm{l}^{2}\right)^{1 / 2}
$$

where $\mathrm{h}, \mathrm{k}$, and $\mathrm{l}$ are Miller indices of the crystal planes and $\mathrm{d}$ is the interplanar distance for the hkl planes. The value of "a" marginally decreased with an increase in the $\mathrm{Cr}$ concentration due to the different sizes of $\mathrm{Cr}^{3+}(0.615 \AA)$ and $\mathrm{Fe}^{3+}$ $(0.645 \AA)$. Table 1 demonstrates the influence of $\mathrm{Cr}$ concentration on the lattice constants of CrZF samples; the results

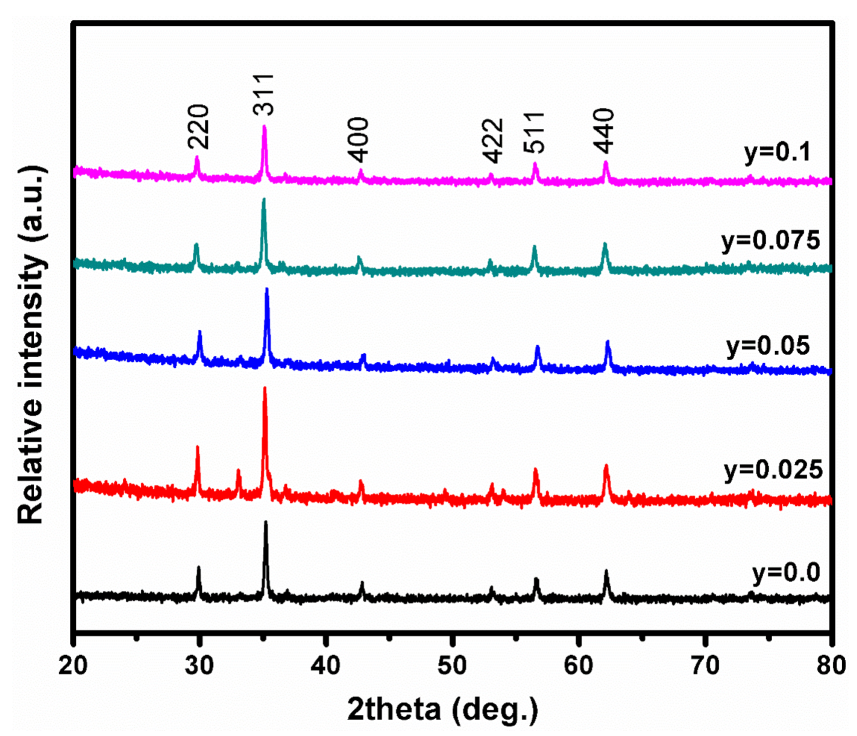

Fig. 3. XRD patterns of $\mathrm{Cr}_{\mathrm{y}} \mathrm{ZnFe}_{2 \cdot \mathrm{y}} \mathrm{O}_{4}(\mathrm{y}=0,0.025,0.050$, 0.075 , and 0.1 ) samples sintered at $750^{\circ} \mathrm{C}$ for $4 \mathrm{~h}$. 
Table 1. The Influence of $\mathrm{Cr}^{3+}$ Doping (y) on the Structural Parameters of Samples $\mathrm{Cr}_{\mathrm{y}} \mathrm{ZnFe}_{2 \cdot \mathrm{y}} \mathrm{O}_{4}$ where $(0 \leq \mathrm{y} \leq 0.1)$

\begin{tabular}{cccccccccccc}
\hline \multirow{2}{*}{$\begin{array}{c}\text { Composition } \\
(\mathrm{y})\end{array}$} & $\begin{array}{c}\text { Crystal-lite } \\
\text { size ' } D_{\mathrm{XRD}} \text { ' }\end{array}$ & $\begin{array}{c}\text { Lattice } \\
\text { constant }\end{array}$ & $\begin{array}{c}\text { Unit cell } \\
\text { volume } \\
(\mathrm{nm})\end{array}$ & $\begin{array}{c}\text { X-ray }\left(\mathrm{A}^{0}\right) \\
\text { density }\end{array}$ & $\begin{array}{c}\text { Physical } \\
\left(\mathrm{a}^{3}\right)\end{array}$ & $\begin{array}{c}\text { density } \\
\left(\mathrm{g} / \mathrm{cm}^{3}\right)\end{array}$ & $\begin{array}{c}\text { Bond length } \\
\left(\mathrm{g} / \mathrm{cm}^{3}\right)\end{array}$ & A-O & B-O & \multicolumn{2}{c}{ Ionic radii } \\
\hline 0.0 & 22.39 & 8.407 & 594.19 & 5.351 & 4.553 & 1.9183 & 2.0389 & 0.5983 & 0.7189 \\
0.025 & 23.90 & 8.458 & 605.06 & 5.255 & 4.381 & 1.9269 & 2.0480 & 0.6069 & 0.728 \\
0.05 & 30.29 & 8.425 & 598.01 & 5.316 & 4.354 & 1.9424 & 2.0405 & 0.6224 & 0.7205 \\
0.075 & 27.27 & 8.477 & 609.15 & 5.205 & 4.361 & 1.9429 & 2.0410 & 0.6229 & 0.721 \\
0.1 & 36.13 & 8.472 & 608.08 & 5.229 & 4.394 & 1.9428 & 2.0408 & 0.6227 & 0.719 \\
\hline
\end{tabular}

were consistent with Vegard's law. ${ }^{21,30)}$

The average crystallite size $\left(\mathrm{D}_{\mathrm{XRD}}\right)$ values for the powder samples were determined using the Debye-Scherrer formula:

$$
\mathrm{D}_{\mathrm{XRD}}=\frac{0.89 \lambda}{\beta \operatorname{Cos} \theta}
$$

Where, $\lambda$ stands for the incident X-ray wavelength $(\mathrm{Cu} \mathrm{K} \alpha$ radiation), $\beta$ stands for full-width at half maximum (FWHM) in radians in the $2 \theta$ scale, $\theta$ is the Bragg angle, $D_{\text {XRD }}$ is the crystallite size in $\mathrm{nm}$. To obtain $\beta$ and $\theta$ values for all samples, the Gaussian fitting model was adopted. The particle sizes of the samples increased due to the replacement of $\mathrm{Fe}^{3+}$ cations by $\mathrm{Cr}^{3+}$ ions with a smaller radius. $\mathrm{D}_{\mathrm{XRD}}$ increased from $22.39 \mathrm{~nm}$ to $36.13 \mathrm{~nm}$ with an increase in the $\mathrm{Cr}$ concentration $(\mathrm{y}=0.0-0.1)$. The X-ray densities $(\mathrm{dx})$ of all $\mathrm{CrZF}$ samples were determined using the following formula $^{31)}$ :

$$
\mathrm{dx}=\frac{\mathrm{ZM}}{\mathrm{Na}^{3}}
$$

where $\mathrm{Z}=$ a constant $(\mathrm{Z}=8$; the total number of molecules in each unit cell), $\mathrm{M}=$ molecular weight $\left(\mathrm{g} \cdot \mathrm{mole}^{-1}\right)$, and $\mathrm{N}=$ Avogadro's number $\left(6.023 \times 10^{23}\right.$ atoms $\left.\cdot \mathrm{mole}^{-1}\right)$.

The skeletal density (ds) values were obtained by measuring the dry and suspended weights of the samples in xylene according to Archimedes' principle:

$$
\mathrm{ds}=\frac{\mathrm{w} \rho}{w-w^{\prime}}
$$

where $\mathrm{w}$ is the weight of the sample in air (g), w' is the weight of the sample in xylene (g), and $\rho$ is the density of xylene $\left(\mathrm{g} \cdot \mathrm{cm}^{-3}\right)$.

From the skeletal and X-ray densities of the samples, the percentage porosity (p) was determined using the following relation $^{32)}$ :

$$
p=\left(1-\frac{d s}{d x}\right) 100 \%
$$

The tetrahedral and octahedral site bond lengths (A-O, B$\mathrm{O})$ and ionic radii $\left(\mathrm{r}_{\mathrm{A}}, \mathrm{r}_{\mathrm{B}}\right)$ of the cubic spinel structures were calculated using the following formulae ${ }^{33)}$.

$$
A-O=\left(u-\frac{1}{4}\right) a \sqrt{3}
$$

$$
\begin{aligned}
& B-O=\left(\frac{5}{8}-u\right) a \\
& r_{A}=\left(u-\frac{1}{4}\right) a \sqrt{3}-r\left(O^{2-}\right) \\
& r_{B}=\left(\frac{5}{8}-u\right) a-r\left(O^{2-}\right)
\end{aligned}
$$

where, $\mathrm{u}$ and $\mathrm{r}\left(\mathrm{O}^{2-}\right)$ are the oxygen ion parameter and radius of oxygen ion $(\sim 1.32 \AA)$, respectively. Table 1 clearly demonstrates the effect of $\mathrm{Cr}$ doping concentration on the crystallite size, lattice constant, X-ray density, physical density, bond length, ionic radii, etc.

\subsection{FT-IR analysis}

FT-IR spectroscopy was performed to determine the fundamental changes and tetrahedral and octahedral sites of spinel ferrites. Moreover, from the FTIR spectra, the impurity states and chemical substances present on the particle surface were determined. Fig. 4 shows the transmittance spectra with two main broad metal-oxygen bands in the range of $400-600 \mathrm{~cm}^{-1}$, indicating the presence of a pure cubic CrZF spinel phase in all samples. ${ }^{34)}$ The higher wave number $\mathrm{v}_{1}$ absorption band, which is generally observed in the range of $544-569 \mathrm{~cm}^{-1}$, was attributed to the vibration of

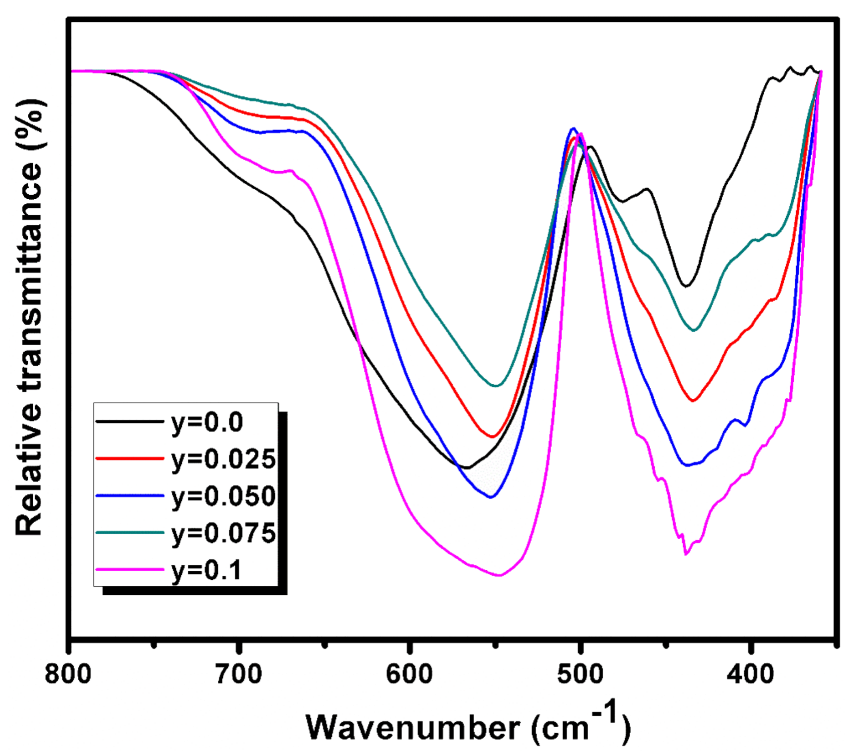

Fig. 4. FTIR spectra of $\mathrm{Cr}_{\mathrm{y}} \mathrm{ZnFe}_{2 \mathrm{y}} \mathrm{O}_{4}(\mathrm{y}=0,0.025,0.050$, 0.075 , and 0.1 ) samples sintered at $750^{\circ} \mathrm{C}$. 
Table 2. The Effect of $\mathrm{Cr}^{3+}$ Doping (y) on Porosity, Grain Size, and Position of FTIR Absorption Bands $\left(v_{1}, v_{2}\right)$ of Sample $\mathrm{Cr}_{\mathrm{y}} \mathrm{ZnFe}_{2-\mathrm{y}} \mathrm{O}_{4}$ where $(0 \leq \mathrm{y} \leq 0.1)$

\begin{tabular}{cccccc}
\hline \multirow{2}{*}{$\begin{array}{c}\text { Chromium } \\
\text { concentration } \\
(\mathrm{y})\end{array}$} & $\begin{array}{c}\text { Porosity } \\
(\%)\end{array}$ & $\begin{array}{c}\text { Grain size } \\
\mathrm{G}_{\mathrm{d}}\end{array}$ & $\begin{array}{c}\text { Absorption band } \\
(\mu \mathrm{m})\end{array}$ & & \multicolumn{2}{c}{\begin{tabular}{c}
$\mathrm{v}_{1}$ \\
\cline { 4 - 5 }
\end{tabular}} & $\mathrm{vm}_{2} \mathrm{v}_{1}-\mathrm{v}_{2}$ & \\
\hline 0.0 & 17.52 & 0.23 & 569 & 439 & 130 \\
0.025 & 19.95 & 0.22 & 550 & 435 & 115 \\
0.05 & 22.09 & - & 551 & 432 & 119 \\
0.075 & 19.35 & 0.20 & 549 & 432 & 117 \\
0.1 & 19 & 0.19 & 544 & 436 & 108 \\
\hline
\end{tabular}

the tetrahedral metal-oxygen and the lower wave number $\mathrm{u}_{2}$ absorption band observed in the range of $432-439 \mathrm{~cm}^{-1}$ was attributed to octahedral metal-oxygen bond stretching vibration. The absorption bands at $439 \mathrm{~cm}^{-1}$ and $569 \mathrm{~cm}^{-1}$ were assigned to the octahedral and tetrahedral sites of spinel zinc ferrite. The $v_{1}$ band observed at around 544-551 $\mathrm{cm}^{-1}$ for the Cr-doped spinel CrZF ( $\mathrm{y}=0.025,0.05,0.075$, and 0.1 ) was assigned to the tetrahedral site and the $\mathrm{u}_{2}$ band observed at $432-436 \mathrm{~cm}^{-1}$ was assigned to the $\mathrm{Fe}^{3+}-\mathrm{O}^{2-}$ vibration at the octahedral location; moreover, the shift in the $\mathrm{v}_{1}$ band location was attributed to the increase in the doping amount of $\mathrm{Cr}^{3+}$ ions in zinc ferrite As the $\mathrm{Cr}$ concen-
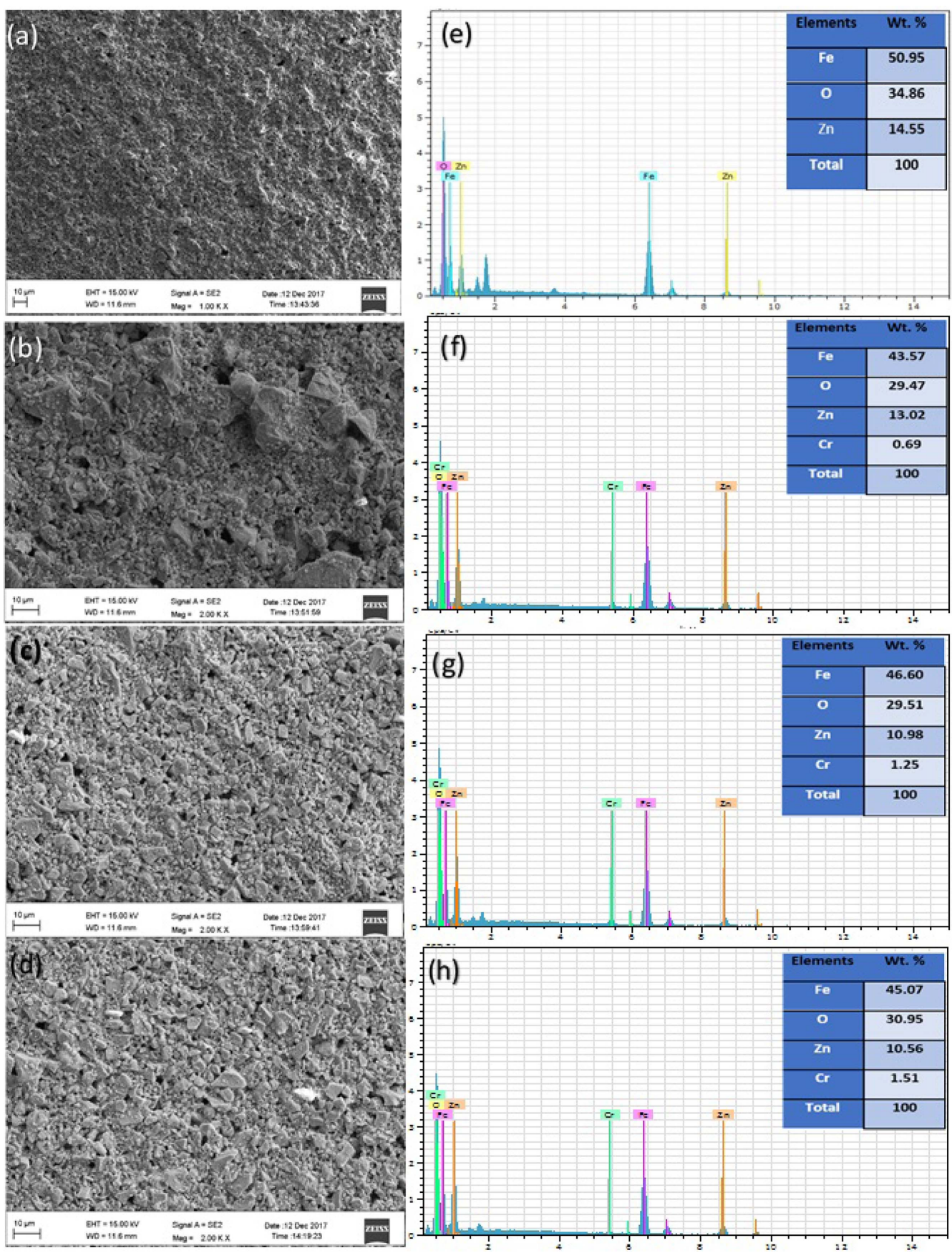

Fig. 5. FE-SEM and EDS data for $\mathrm{Cr}_{\mathrm{y}} \mathrm{ZnFe}_{2-\mathrm{y}} \mathrm{O}_{4}(\mathrm{y}=0,0.025,0.050,0.075$, and 0.1$)$ samples sintered at $750^{\circ} \mathrm{C}$. 
tration increased, $v_{1}$ decreased (i.e., from $550 \mathrm{~cm}^{-1}$ for $\mathrm{Cr}_{0.025} \mathrm{ZnFe}_{1.975} \mathrm{O}_{4}$ to $544 \mathrm{~cm}^{-1}$ for $\left.\mathrm{Cr}_{0.1} \mathrm{ZnFe}_{1.9} \mathrm{O}_{4}\right)$. This indicated that the $\mathrm{Cr}^{3+}$ ions replaced a proportional amount of $\mathrm{Fe}^{3+}$ ions in the octahedral sites, resulting in a reduction in the length of the metal-oxygen bond, which was reflected by an increase in the broadening of the absorption band, as presented in Table $2 .{ }^{21)}$

\subsection{Morphological and elemental analysis}

The FE-SEM images of CrZF ( $\mathrm{y}=0.0,0.025,0.075$, and 0.1 ) samples sintered at $750^{\circ} \mathrm{C}$ are presented in Fig. 5 (a-d). In Fig. 5, nearly uniform and agglomerated grains are observed. The grain size of the sample is usually calculated by the linear intercept method using equation (10). ${ }^{35}$

$$
\mathrm{G}_{\mathrm{d}}=\frac{1.5 \mathrm{~L}}{\mathrm{MN}}
$$

where L, M, and $\mathrm{N}$ are the total length of the test line, magnification, and number of intercepts, respectively. The morphology and size of particles were influenced by the Crdoping content and calcination temperature, and the size ranged from $0.19-0.23 \mu \mathrm{m}$. With an increase in the Cr content, the particle size decreased from $0.23 \mu \mathrm{m}$ to $0.19 \mu \mathrm{m}$, which was larger than $\mathrm{D}_{\mathrm{XRD}}$ of CrZF thick films.

The percentage elemental composition of the prepared CrZF thick film was investigated by the EDS technique. Fig. 5(e-h) present the EDS profiles of the CrZF samples. EDS was performed to verify homogeneity of the prepared samples and examine the presence of impurities originating from the synthesis process. The compositional percentages of $\mathrm{Fe}, \mathrm{Zn}, \mathrm{Cr}$, and $\mathrm{O}$ in the $\mathrm{Cr}$-doped zinc ferrite samples are listed in Table 3 as a function of the $\mathrm{Cr}$ doping concentration. The EDS data for the CrZF ( $\mathrm{y}=0.0,0.025,0.075$, and 0.1) samples revealed the doping level (wt.\%) of $\mathrm{Cr}$ in the samples to be $0.69,1.25$, and 1.51 for $y=0.025,0.075$, and 0.1 , respectively. However, the wt.\% of Fe decreased in the order $50.95,43.57,46.60$, and 45.07 with increasing y $(0.0$, $0.025,0.075$, and 0.1 , respectively).

\subsection{BET analysis}

$\mathrm{N}_{2}$ adsorption-desorption measurements were performed to determine the changes in the specific surface area and pore size as a function of the Cr substitution level. Type (IV) hysteresis loops for all CrZF ( $\mathrm{y}=0.0-0.1$ ) samples obtained at $77 \mathrm{~K}$ are depicted in Fig. 6; the Type (IV) hysteresis loop

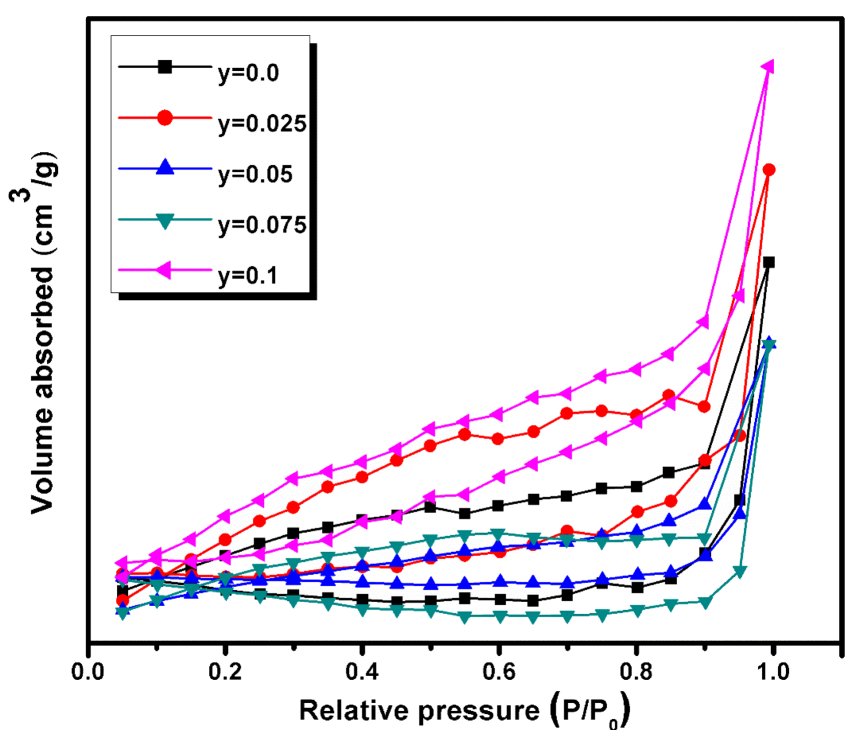

Fig. 6. $\mathrm{N}_{2}$ adsorption-desorption isotherms of $\mathrm{Cr}_{\mathrm{y}} \mathrm{ZnFe}_{2-\mathrm{y}} \mathrm{O}_{4}$ (y $=0,0.025,0.050,0.075$, and 0.1) samples.

is characteristic to porous materials. ${ }^{36)}$ The surface area values for nanocrystalline CrZF ( $\mathrm{y}=0.0,0.025,0.05,0.075$ and 0.1 ) samples annealed at $750^{\circ} \mathrm{C}$ as a function of the $\mathrm{Cr}$ doping level are tabulated in Table 3. The specific surface area values for CrZF ( $\mathrm{y}=0.0,0.025,0.05,0.075$, and 0.1 ) samples are $5.245,10.411,5.265,4.422$, and $11.689 \mathrm{~m}^{2} \cdot \mathrm{g}^{-1}$, and the cumulative pore volumes are found to be $0.025,0.033,0.021$, 0.020 , and $0.039 \mathrm{~cm}^{3} \cdot \mathrm{g}^{-1}$, respectively. The BJH pore volume analysis revealed an average pore diameter of $\sim 3-4 \mathrm{~nm}$.

\subsection{DC electrical resistivity analysis}

Spinel ferrites are well-known high-resistance materials and their conductivity is determined by the drift mobility of electric carriers between ferrous and ferric ions (with +2 and +3 valence states), which are thermally activated. The temperature-dependent electrical resistivity $(\rho)$ of $\mathrm{CrZF}$ samples was investigated in the temperature range of 30$600^{\circ} \mathrm{C}$. Fig. 7 presents the plot of temperature dependency of the DC electrical resistivity versus $10^{3} / \mathrm{T}$. The electrical resistivity of the synthesized samples exhibited temperature-dependent brakes among linear shape with increasing temperature, suggesting their semi-conductive nature. This change in the resistivity with the $\mathrm{Cr}$ content could be explained on the basis of the hopping mechanism. It is well

Table 3. The Variations in Physical Properties of Samples $\mathrm{Cr}_{\mathrm{y}} \mathrm{ZnFe}_{2-\mathrm{y}} \mathrm{O}_{4}$ where $(0 \leq \mathrm{y} \leq 0.1)$ Due $\mathrm{Cr}^{3+}$ Concentration

\begin{tabular}{|c|c|c|c|c|c|c|c|}
\hline \multirow{2}{*}{$\begin{array}{l}\text { Chromium } \\
\text { concentration } \\
\text { (y) }\end{array}$} & \multirow{2}{*}{$\begin{array}{l}\text { Pore size } \\
\quad(\mathrm{nm})\end{array}$} & \multirow{2}{*}{$\begin{array}{l}\text { Surface area } \\
\left(\mathrm{m}^{2} / \mathrm{g}\right)\end{array}$} & \multirow{2}{*}{$\begin{array}{l}\text { Pore volume } \\
\quad\left(\mathrm{cm}^{3} / \mathrm{g}\right)\end{array}$} & \multicolumn{4}{|c|}{ Wt. Abundance (\%) } \\
\hline & & & & Iron & Oxygen & Zinc & Chromium \\
\hline 0.0 & 3.822 & 5.245 & 0.025 & 50.95 & 34.86 & 14.55 & - \\
\hline 0.025 & 3.408 & 10.411 & 0.033 & 43.57 & 29.47 & 13.02 & 0.69 \\
\hline 0.05 & 3.054 & 5.265 & 0.021 & - & - & - & - \\
\hline 0.075 & 3.819 & 4.422 & 0.020 & 46.60 & 29.51 & 10.98 & 1.25 \\
\hline 0.1 & 3.820 & 11.689 & 0.039 & 45.07 & 30.95 & 10.56 & 1.51 \\
\hline
\end{tabular}




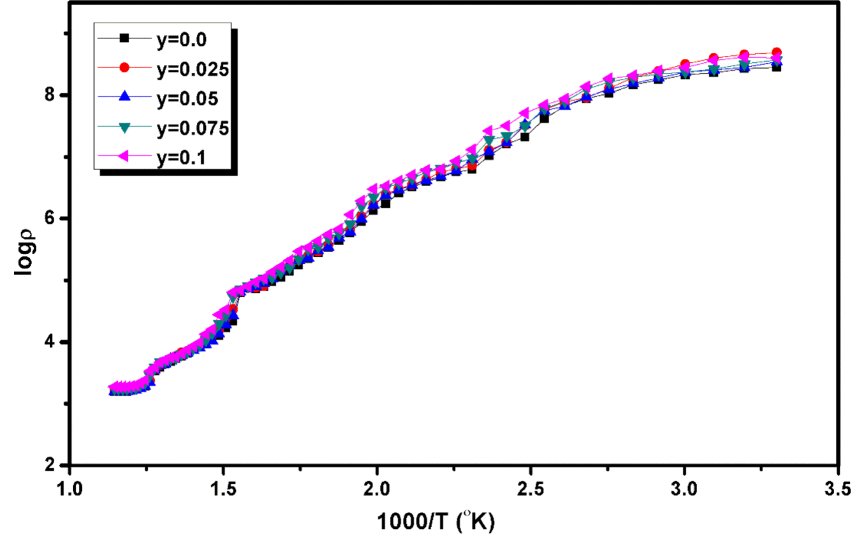

Fig. 7. Temperature-dependence of $\mathrm{DC}$ electrical resistivity against 1000/T for $\mathrm{Cr}_{\mathrm{y}} \mathrm{ZnFe}_{2-\mathrm{y}} \mathrm{O}_{4}(\mathrm{y}=0,0.025,0.050$, 0.075 , and 0.1) samples.

known that the distribution of cations, grain size, and porosity have a strong influence on the resistivity of ferrites. At high temperatures, ferrites acquire thermal energy and oxygen ions escape from $\mathrm{CrZF}$ in the form of $\mathrm{ZnO}$, creating oxygen vacancies to maintain charge balance transformation of the $\mathrm{Fe}^{3+}$ to $\mathrm{Fe}^{2+}$ ions, retaining spinel lattice neutrality. In undoped $\mathrm{ZF}, \mathrm{Zn}^{2+}$ and $\mathrm{Fe}^{3+}$ ions occupy the tetrahedral (A) and octahedral (B) interstitial sites, respectively, whereas in Cr-doped zinc ferrite, with increasing $\mathrm{Cr}^{3+}$ doping amount, the concentration of $\mathrm{Fe}^{3+}$ ions at the B-sites decreases; consequently, $\mathrm{Cr}^{3+}$ ions at the B-sites hamper electron hopping between $\mathrm{Fe}$ ions by blocking the $\mathrm{Fe}^{2+} \leftrightarrow \mathrm{Fe}^{3+}$ exchange, which increases the resistivity. Notably, the amount of $\mathrm{Fe}^{3+}$ ions at the octahedral sites decreases as the $\mathrm{Cr}^{3+}$ doping concentration increases and $\mathrm{Cr}^{3+}$ ions do not take part in the hopping mechanism. As observed in Fig. 7, the resistivity increased as the $\mathrm{Cr}^{3+}$ substitution level in Cr-doped zinc ferrite increased. The mesoporous CrZF nanostructures were composed of grains with sizes in the range of $0.19-0.23 \mu \mathrm{m}$. The samples contained numerous grain boundaries, which acted as obstacles to the flow of electrons, obstructing hopping of charge carriers; this resulted in increased resistivity. $^{37)}$

\subsection{Magnetic analysis}

The room-temperature magnetization vs. applied field curves (M-H loops) for Cr-Zn ferrite samples are shown in Fig. 8. For all samples, the magnetization reached saturation at a magnetic field of 15000 Oe. The magnetic properties were determined from Fig. 8 and all values are listed in Table 4. The saturation magnetization $(\mathrm{Ms})$ significantly increased with the addition of $\mathrm{Cr}^{3+}$. For CrZF samples, when $\mathrm{y}$ was increased from 0.025 to 0.1 , the $\mathrm{Ms}$ value increased from $0.0237 \mathrm{emu} \cdot \mathrm{g}^{-1}$ to $0.1498 \mathrm{emu} \cdot \mathrm{g}^{-1}$. Mostly, the $\mathrm{Cr}^{3+}$ replaced the $\mathrm{Fe}^{3+}$ in octahedral sites, decreasing the magnetic moment of $\mathrm{CrZF}$ at low doping concentrations. Hc values were clearly affected by $\mathrm{Cr}$ substitution. As observed from Table 4, with an increase in the $\mathrm{Cr}^{3+}$ concentration, the

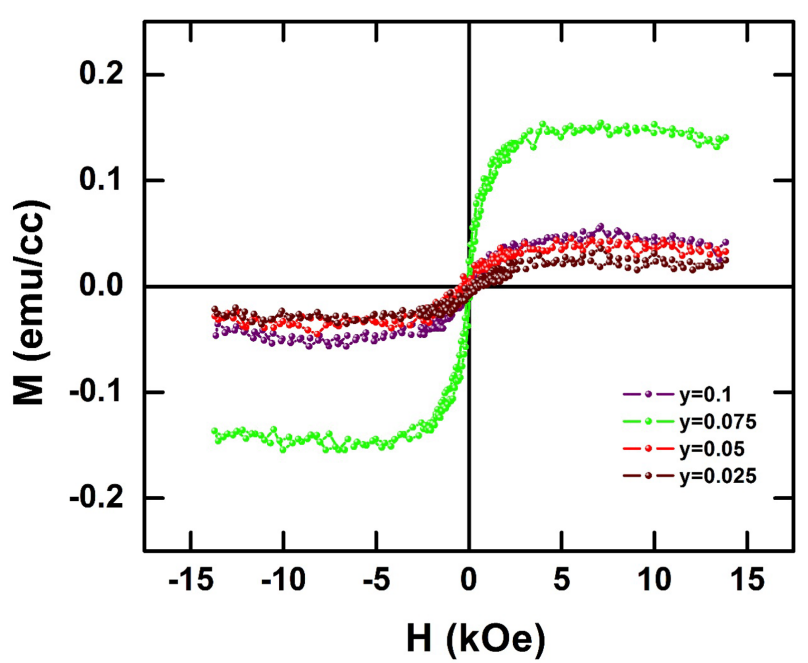

Fig. 8. Magnetic hysteresis loops of $\mathrm{Cr}_{\mathrm{y}} \mathrm{ZnFe}_{2 \mathrm{y}} \mathrm{O}_{4}(\mathrm{y}=0.025$, $0.05,0.075$, and 0.1 ) samples at room temperature.

Hc value decreased for samples with $\mathrm{y}=0.025$ and 0.05 , while it increased for samples with $\mathrm{y}=0.075$ and 0.1 . As reported, the Co-doped $\mathrm{ZnFe}_{2} \mathrm{O}_{4}$ sample exhibited the highest coercivity value ( $1834 \mathrm{Oe})$, which was attributed to the particle size effect, nature of the dopant, and high doping concentration. ${ }^{22)}$

As the applied field increased, the magnetization increased from zero in both directions, and saturation in the hysteresis loop was not observed, which could be due to the presence of non-magnetic $\mathrm{Zn}^{2+}$ ions and weakly magnetic $\mathrm{Cr}^{3+}$ ions in the spinel ferrites. Usually, three kinds of superexchange interactions occur in spinel ferrites (A-A, B-B, and A-B), according to Neel's two-sublattice model. The strength of A-B interaction was higher than those of the other two interactions. $\mathrm{ZnFe}_{2} \mathrm{O}_{4}$ showed the lowest magnetization. ${ }^{22)}$ However, doping of $\mathrm{Cr}$ into zinc ferrite slightly decreased the magnetization for samples with $\mathrm{y}=0.025$ and 0.05 due to the substitution of weakly magnetic $\mathrm{Cr}^{3+}$ ions from B-site replaces the comparatively high magnetic $\mathrm{Fe}^{3+}$ ions in B-site was affected due to the A-B interaction. Non-linear magnetization values were obtained because of the presence of $\mathrm{Zn}^{2+}$ ions, which caused spin canting. The $\mathrm{Cr}_{0.025} \mathrm{ZnFe}_{1.975} \mathrm{O}_{4}$ sample exhibited a low coercivity value of 40 Oe because the replacement of $\mathrm{Fe}^{3+}$ by $\mathrm{Cr}^{3+}$ ions reinforced the sublattice interaction, indicating that the particle was easily magne-

Table 4. The Effects of $\mathrm{Cr}^{3+}$ Doping Concentration on the Magnetic Properties of Samples $\mathrm{Cr}_{\mathrm{y}} \mathrm{ZnFe}_{2-\mathrm{y}} \mathrm{O}_{4}$ where $(0.025 \leq \mathrm{y} \leq 0.1)$

\begin{tabular}{ccccc}
\hline $\begin{array}{c}\text { Composition } \\
\text { y }\end{array}$ & $\begin{array}{c}\mathrm{Ms} \\
(\mathrm{emu} / \mathrm{cc})\end{array}$ & $\begin{array}{c}\mathrm{Mr} \\
(\mathrm{emu} / \mathrm{cc})\end{array}$ & $\mathrm{Mr} / \mathrm{Ms}$ & $\begin{array}{c}\mathrm{Hc} \\
(\mathrm{Oe})\end{array}$ \\
\hline 0.025 & 0.0237 & 0.0022 & 0.0912 & 40 \\
0.050 & 0.0442 & 0.0042 & 0.0943 & 50 \\
0.075 & 0.0472 & 0.0019 & 0.0412 & 164 \\
0.1 & 0.1498 & 0.0166 & 0.1109 & 70 \\
\hline
\end{tabular}


tized without any flux loss. The changing nature of hysteresis loops with increasing $\mathrm{Cr}$ concentration makes this type of ferrites suitable for various applications, such as microwave devices, transformer cores, etc.

\section{Conclusions}

In the present study, we produced compositionally different nanoparticles of CrZF $(0 \leq \mathrm{y} \leq 0.1)$ by combining highly soluble nitrate salts of $\mathrm{Fe}, \mathrm{Cr}$, and $\mathrm{Zn}$ in the presence of CTAB by a chemical co-precipitation technique at a lower calcination temperature compared to that used in the ceramic method. The TG analysis result of the as-prepared sample revealed that above $450^{\circ} \mathrm{C}$, the stable phase of chromium zinc ferrite was formed. The XRD results proved that the crystallite size increased from $\sim 22 \mathrm{~nm}$ to $36 \mathrm{~nm}$ with the substitution of $\mathrm{Cr}^{3+}$ into the single cubic spinel structure for all CrZF samples. Furthermore, $\mathrm{Cr}^{3+}$ doping-induced changes were investigated by FTIR spectroscopy on the basis of the bond stretching vibrations of tetrahedral and octahedral metal complexes in the range of $400-600 \mathrm{~cm}^{-1}$. After doping of $\mathrm{Cr}^{3+}$ into zinc ferrite samples, certain deviations in the skeletal and X-ray densities, crystallite size, unit cell volume, and ionic length of the tetrahedral and octahedral sites were observed for $\mathrm{ZnFe}_{2} \mathrm{O}_{4}$. The FE-SEM images revealed that all samples were porous and the particles were nearly uniform shaped with an average size of $0.19-0.23 \mu \mathrm{m}$; the average size decreased after the incorporation of $\mathrm{Cr}^{3+}$ due to agglomeration at the elevated calcination temperature. The influence of $\mathrm{Cr}^{3+}$ ions caused noticeable variations in the structural, morphological, electrical, and magnetic properties of the CrZF $(0 \leq \mathrm{y} \leq 0.1)$ spinel ferrite, which strongly depended on the chemical composition, size, and preferential distribution of cations at (A) and (B) sites. Thus, Cr doping in the zinc ferrite increased the resistivity. The incorporation of $\mathrm{Cr}^{3+}$ ions into zinc ferrite led to a decrease in the saturation magnetization, coercivity, and magnetic moment at very low concentrations, and an increase in the magnetic moments of the unit cells at high concentrations. It was confirmed that the $\mathrm{Cr}-\mathrm{Zn}$ ferrites are soft magnetic materials, which could be used in transformers and motors.

\section{Acknowledgments}

The author (RRP) is grateful to the Department of Metallurgy, College of Engineering, Pune (COEP) Maharashtra, India for their help with the FE-SEM and EDS facility.

\section{REFERENCES}

1. Z. Wang, P. Hong, S. Peng, T. Zou, Y. Yang, X. Xing, Z. Wang, R. Zhao, Z. Yan, and Y. Wang, " $\mathrm{Co}(\mathrm{OH})_{2} @ \mathrm{FeCo}_{2} \mathrm{O}_{4}$ as Electrode Material for High Performance Faradaic Supercapacitor Application,” Electrochim. Acta, 299312 19 (2019).
2. M. Amiri, M. Salavati-Niasari, and A. Akbari, "Magnetic Nanocarriers: Evolution of Spinel Ferrites for Medical Applications," Adv. Colloid Interface Sci., 265 29-44 (2019).

3. K. R. Sanadi, S. P. Patil, V. G. Parale, H. H. Park, G. S. Kamble, and H. M. Yadav, "Preparation of Cobalt Substituted Zinc Aluminum Chromite: Photocatalytic Properties and Suzuki Cross-Coupling Reaction," J. Mater. Sci.: Mater. Electron., 29 [9] 7274-86 (2018).

4. V. D. Phadtare, V. G. Parale, G. K. Kulkarni, H. H. Park, and V. R. Puri, "Enhanced Microwave Absorption of Screen-Printed Multiwalled Carbon Nanotube/ $\mathrm{Ca}_{1-\mathrm{x}} \mathrm{Ba}_{\mathrm{x}}$ $\mathrm{Bi}_{2} \mathrm{Nb}_{2} \mathrm{O}_{9}(0 \leq \mathrm{x} \leq 1)$ Multilayered Thick Film Composites," J. Alloys Compd., 765 878-87 (2018).

5. V. D. Phadtare, V. G. Parale, G. K. Kulkarni, H. H. Park, and V. R. Puri, "Microwave Dielectric Properties of Barium Substituted Screen Printed $\mathrm{CaBi}_{2} \mathrm{Nb}_{2} \mathrm{O}_{9}$ Ceramic Thick Films," Ceram. Int., 44 [7] 7515-23 (2018).

6. H. S. Jadhav, A. Roy, G. M. Thorat, and J. G. Seo, "Facile and Cost-Effective Growth of Highly Efficient $\mathrm{MgCo}_{2} \mathrm{O}_{4}$ Electro Catalyst for Methanol Oxidation," Inorg. Chem. Front., 5 1115-20 (2018).

7. V. G. Parale, K. Y. Lee, and H. H. Park, "Flexible and Transparent Silica Aerogel: An Overview," J. Korean Ceram. Soc., 54 [3] 184-99 (2017).

8. A. I. Ivanets, V. Srivastava, M. Yu. Roshchina, M. Sillanpää, V. G. Prozorovich, and V. V. Pankov, "Magnesium Ferrite Nanoparticles as a Magnetic Sorbent for the Removal of $\mathrm{Mn}^{2+}, \mathrm{Co}^{2+}, \mathrm{Ni}^{2+}$ and $\mathrm{Cu}^{2+}$ from Aqueous Solution," Ceram. Int., 44 [8] 9097-104 (2018).

9. D. S. Nair and M. Kurian, "Chromium-Zinc Ferrite Nanocomposites for the Catalytic Abatement of Toxic Environmental Pollutants under Ambient Conditions," J. Hazardous Mater., 344 925-41 (2018).

10. P. V. Gaikwad, R. J. Kamble, S. J. M. Gavade, S. R. Sabale, and P. D. Kamble, "Magneto-Structural Properties and Photocatalytic Performance of Sol-Gel Synthesized Cobalt Substituted Ni Cu Ferrites for Degradation of Methylene Blue under Sunlight," Phys. B, 554 79-85 (2019).

11. R. A. Pawar, S. M. Patange, A. R. Shitre, S. K. Gore, S. S. Jadhav, and S. E. Shirsath, "Crystal Chemistry and Single-Phase Synthesis of $\mathrm{Gd}^{3+}$ Substituted Co-Zn Ferrite Nanoparticles for Enhanced Magnetic Properties," RSC $A d v ., 8$ [44] 25258-67 (2018).

12. M. M. Rahman, S. B. Khan, M. Faisal, A. M. Asiri, and K. A. Alamry, "Highly Sensitive Formaldehyde Chemical Sensor Based on Hydrothermally Prepared Spinel $\mathrm{ZnFe}_{2} \mathrm{O}_{4}$ Nanorods," Sens. Actuators, B, 171-172 932-37 (2012).

13. J. Smit and H. P. J. Wijn, Ferrites-Physical Properties of Ferromagnetic in Oxides Relation to Their Technical Application; Wiley, New York, 1959.

14. H. Knock and H. Dannheim, "Temperature Dependence of the Cation Distribution in Magnesium Ferrite," Phys. Status Solidi A, 37 [2] K135-37 (1976).

15. S. S. Desai, S. M. Patange, A. D. Patil, S. K. Gore, and S. S. Jadhav, "Effects of $\mathrm{Zn}^{2+}-\mathrm{Zr}^{4+}$ Ions on the Structural, Mechanical, Electrical, and Optical Properties of Cobalt Ferrites Synthesized via the Sol-Gel Route," J. Phys. Chem. Solids, 133 171-77 (2019). 
16. N. Rezlescu, E. Rezlescu, P. D. Popa, M. L. Craus, and L. Rezlescu, "Copper Ions Influence on the Physical Properties of a Magnesium-Zinc Ferrite," J. Magn. Magn. Mater., 182 [1-2] 2670-79 (2017).

17. M. Wang, M. Yang, X. Zhao, L. Ma, X. Shen, and G. Cao, "Spinel $\mathrm{LiMn}_{2-\mathrm{x}} \mathrm{Si}_{\mathrm{x}} \mathrm{O}_{4}(\mathrm{x}<1)$ through $\mathrm{Si}^{4+}$ Substitution as a Potential Cathode Material for Lithium-Ion Batteries," Sci. China Mater., 59 [7] 558-66 (2016).

18. M. Lakshmi, K. V. Kumar, and K. Thyagarajan, "An Investigation of Structural and Magnetic Properties of Cr-Zn Ferrite Nanoparticles Prepared by a Sol-Gel Process," J Nanostruct. Chem., 5 [4] 365-73 (2015).

19. D. S. Nair and M. Kuriand, "Chromium-Zinc Ferrite Nanocomposites for the Catalytic Abatement of Toxic Environmental Pollutants under Ambient Conditions," J. Hazard. Mater., 344 925-41 (2018).

20. A. I. Borhan, V. Hulea, A. R. Iordan, and M. N. Palamaru, " $\mathrm{Cr}^{3+}$ and $\mathrm{Al}^{3+}$ Co-Substituted Zinc Ferrite: Structural Analysis, Magnetic and Electrical Properties," Polyhedron, 70 110-18 (2014).

21. D. S. Nair and M. Kurian, "Chromium-Zinc Ferrite Nanocomposites for the Catalytic Abatement of Toxic Environmental Pollutants under Ambient Conditions," J. Hazard. Mater., 344 925-41 (2018).

22. R. R. Powar, V. D. Phadtare, V. G. Parale, H.-H. Park, S. Pathak, P. R. Kamble, P. B. Piste, and D. N. Zambare, "Structural, Morphological, and Magnetic Properties of $\mathrm{Zn}_{\mathrm{x}} \mathrm{Co}_{1-\mathrm{x}} \mathrm{Fe}_{2} \mathrm{O}_{4}(0 \leq \mathrm{x} \leq 1)$ Prepared Using a Chemical CoPrecipitation Method," Ceram. Int., 44 [17] 20782-89 (2018).

23. M. Ebirahmi, R. R. Shahraki, S. A. S Ebirahimi, and S. M. Masoudpanah, "Magnetic Properties of Zinc Ferrite Nanoparticles Synthesized by Coprecipitation Method," J. Supercond. Novel Magn., 27 [6] 1587-92 (2014).

24. A. Manikandan, J. J. Vijaya, M. Sundararajan, C. Meganathan, L. J. Kennedy, and M. Bououdina, "Optical and Magnetic Properties of Mg-doped $\mathrm{ZnFe}_{2} \mathrm{O}_{4}$ Nanoparticles Prepared by Rapid Microwave Combustion Method," Superlattices Microstruct., 64 118-31 (2013).

25. N. Kasapoglu, A. Baykal, Y. Koseoglu, and M. S. Toprak, "Microwave-Assisted Combustion Synthesis of $\mathrm{CoFe}_{2} \mathrm{O}_{4}$ with Urea, and its Magnetic Characterization," Scr. Mater.,
57 [5] 441-44 (2007).

26. Y. Koseoglu, M. I. O. Oleiwi, R. Yilgin, and A. N. Kocbay, "Effect of Chromium Addition on the Structural, Morphological and Magnetic Properties of Nano-Crystalline Cobalt Ferrite System," Ceram. Int., 38 [8] 6671-76 (2012).

27. A. A. Birajdar, S. E. Shirsath, R. H. Kadam, S. M. Patange, D. R. Mane, and A. R. Shitre, "Frequency and Temperature Dependent Electrical Properties of $\mathrm{Ni}_{0.7} \mathrm{Zn}_{0.3} \mathrm{Cr}_{\mathrm{x}} \mathrm{Fe}_{2-\mathrm{x}} \mathrm{O}_{4}(0 \leq$ $\mathrm{x} \leq$ 0.5)," Ceram. Int., 38 [4] 2963-70 (2012).

28. K. A. M. Khalaf, A. D. Al-Rawas, H. M. Widatallah, K. S. Al-Rashdi, A. Sellai, A. M. Gismelseed, M. Hashim, S. K. Jameel, M. S. Al-Ruqeishi, K. O. Al-Riyami, M. Shongwe, and A. H. Al-Rajhi, "Influence of $\mathrm{Zn}^{2+}$ Ions on the Structural and Electrical Properties of $\mathrm{Mg}_{1-\mathrm{x}} \mathrm{Zn}_{\mathrm{x}} \mathrm{FeCrO}_{4}$ Spinels," $J$. Alloys Compd., 657 733-47 (2016).

29. V. D. Phadtare and V. R. Puri, "Studies on Electrical and Dielectric Properties of Co-Precipitated Aurivillius Phase $\mathrm{Ca}_{1-\mathrm{x}} \mathrm{Ba}_{\mathrm{x}} \mathrm{Bi}_{2} \mathrm{Nb}_{2} \mathrm{O}_{9}$ Ceramics," Ceram. Int., 42 [7] 8581-86 (2016).

30. A. R. Denton and N. W. Ashcroft, "Vegard's Law," Phys. Rev. A, 433161 (1991).

31. B. D. Culity, Elements of X-ray Diffraction; Vol. 99, p. 96, Addison Wesley Pub Co Inc, 1967.

32. U. R. Ghodake, N. D. Chaudhari, R. C. Kambale, J. Y. Patil, and S. S. Suryavanshi, "Effect of $\mathrm{Mn}^{2+}$ Substitution on Structural, Magnetic, Electric and Dielectric Properties of Mg-Zn Ferrites," J. Magn. Magn. Mater., 407 60-8 (2016).

33. K. J. Standley, Oxide Magnetic Materials, Oxford at Clarendon Press, London, 1962.

34. R. D. Waldron, "Infrared Spectra of Ferrites," Phys. Rev., 99 [6] 1727 (1955).

35. M. I. Mendelson, "Average Grain Size in Polycrystalline Ceramic," J. Am. Ceramic. Soc., 52 [8] 443-46 (1969).

36. V. Jeseentharani, M. George, B. Jeyaraj, A. Dayalan, and K. S Nagaraja, "Synthesis of Metal Ferrite $\left(\mathrm{MFe}_{2} \mathrm{O}_{4}\right.$, $\mathrm{M}=\mathrm{Co}, \mathrm{Cu}, \mathrm{Mg}, \mathrm{Ni}, \mathrm{Zn}$ ) Nanoparticles as Humidity Sensor Materials," J. Exp. Nanosci., 8 [3] 358-70 (2013).

37. R. H. Kadam, A. Karim, A. B. Kadam, A. S. Gaikwad, and S. E. Shirsath, "Influence of $\mathrm{Cr}^{3+}$ Substitution on the Electrical and Magnetic Properties of $\mathrm{Ni}_{0.4} \mathrm{Cu}_{0.4} \mathrm{Zn}_{0.2} \mathrm{Fe}_{2} \mathrm{O}_{4}$ Nanoparticles," Int. Nano Lett., 228 (2012). 